\title{
Efficacy of Newly Synthesized 44Bu Ultrashort-Acting Beta-Adrenergic Antagonist to Isoprenaline-Induced Tachycardia - Comparison With Esmolol
}

\author{
L. BARTOŠOVÁ, M. FRYDRYCH, G. HULÁKOVÁ, K. BERÁNKOVÁ, \\ V. STRNADOVÁ, P. MOKRÝ1, V. BRUNCLÍK², J. KOLEVSKÁ², \\ M. BÉBAROVÁ 3
}

\begin{abstract}
Department of Human Pharmacology and Toxicology, ${ }^{1}$ Department of Chemical Drugs, Pharmaceutical Faculty, Veterinary and Pharmaceutical University, Brno, Czech Republic

${ }^{2}$ Small Animal Clinic, Faculty of Veterinary Medicine, Veterinary and Pharmaceutical University, Brno, Czech Republic ${ }^{3}$ Department of Physiology, Faculty of Medicine, Masaryk University, Brno, Czech Republic
\end{abstract}

Received August 27, 2003

Accepted June 17, 2004

\begin{abstract}
Bartošová L., M. Frydrych, G. Huláková, K. Beránková, V. Strnadová, P. Mokrý, V. Brunclík, J. Kolevská, M. Bébarová: Efficacy of Newly Synthesized 44Bu Ultrashort-Acting Beta-Adrenergic Antagonist to Isoprenaline-Induced Tachycardia Comparison with Esmolol. Acta Vet. Brno 2004, 73: 171-179.

The aim of this study was in vivo testing of the action of three newly synthesized potential ultrashort acting beta-blockers on the heart rate in the laboratory rat. The tested substance 44Bu was administered to animals with induced tachycardia, in the form of an intravenous bolus in general anaesthesia.

Doses at concentrations of $1.5 \mathrm{mg} \cdot \mathrm{kg}^{-1}, 2.5 \mathrm{mg} \cdot \mathrm{kg}^{-1}$, and $3.5 \mathrm{mg} \cdot \mathrm{kg}^{-1}$ of body mass were tested and the efficacy was compared with placebo. For the heart rate monitoring a computer electrocardiograph was used. Significant $(p<0.05)$ heart rate decrease was recorded for all three tested doses, minimally up to the $14^{\text {th }}$ minute following the intravenous administration.

Bradycardic effect of the compound 44Bu was compared with the action of esmolol under the same experimental conditions. The effects of the compound 44Bu and esmolol were not different in the onset, but in the depth of the heart rate decrease, above all at higher concentrations. It was experimentally verified, that the compound $44 \mathrm{Bu}$ has the properties of an ultrashort acting beta adrenergic receptor blocker.
\end{abstract}

Pharmacology, ester-functional group, bradycardic effect, heart rate, rats

The beta-adrenergic receptor blockers were introduced in the clinical practice in the early 1960s after their effect on blood pressure reduction had been demonstrated. They are widely used in angina pectoris treatment, and since early 1970s, they are evidenced to reduce mortality after myocardial infarction. Nowadays, the most important indications include ischaemic heart disease, arrhythmias, arterial hypertension. Recently they have been used also in certain types of heart failure (Felix et al. 2001), e.g. idiopathic dilatation cardiomyopathy (Hradec et al. 2002). In addition to these basic indications, they are also used in non-cardiologic diseases treatment, such as glaucoma, migraine, hyperthyroidism or anxiety states. Some representatives of the beta-blockers show also a distinct anti-oxidant effect (Bartošíková et al. 1998; Nečas et al. 1997).

However, the beta-blockers possess also a number of adverse effects, such as bradycardia, hypotension, heart failure and bronchospasm, peripheral vasoconstriction (cold extremities syndrome), fatigue, insomnia, depression.

To avoid prolonged action of beta-blockers, ultrashort acting beta-blockers have been developed for intravenous infusion with several minutes of duration of the pharmacological effect, the use of which is much more convenient than the administration of longer acting beta-adrenergic antagonists in critically ill patients (Reilly et al. 1985; Gray 1988).

Address for correspondence:

RNDr. Ladislava Bartošová

Department of Human Pharmacology and Toxicology

Pharmaceutical Faculty, Veterinary and Pharmaceutical University

Palackého 1-3, 61242 Brno, Czech Republic

Phone: + 420541562896

Fax:+ 420541240605

E-mail: bartosoval@vfu.cz

http://www.vfu.cz/acta-vet/actavet.htm 


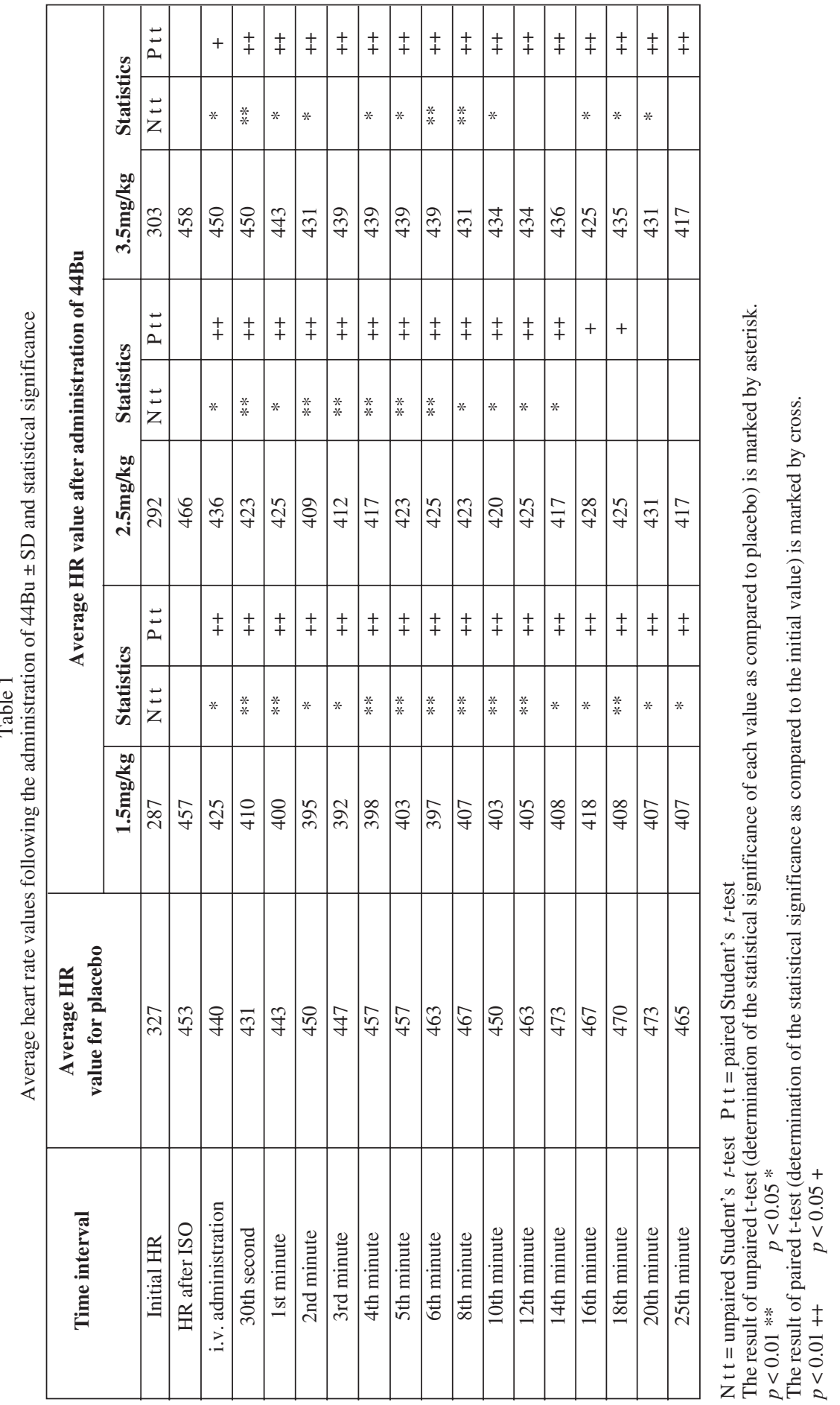


These compounds have a very short elimination half-time, about 10 minutes (Katzung et al. 1995). Steady concentration is achieved by continuous infusion, and the therapeutic effect can be quickly finished by interrupting the infusion.

The ultrashort acting beta-blockers form so far an inconspicuous fraction of the extensive group of beta-adrenolytics. Currently, three ultrashort acting beta-blockers have been synthesized: esmolol (Gorczynski 1985), flestolol (Barton et al. 1986), and landiolol (Atarashi et al. 2000). Their common feature is a short biological elimination half-time, which is achieved by the ester group integration in the side chain on the aromatic nucleus. This group is hydrolyzed rapidly by cholinesterases in plasma or esterases in cytosol or erythrocyte membrane.

In the Czech Republic, the only registered preparation containing ultrashort acting betablocker esmolol is Brevibloc ${ }^{\circledR}$, inj. The effective substance is esmolol hydrochloride (AISLP 2002). Landiolol was introduced to the market under the name of Onoact ${ }^{\circledR}, 50$ inj. in Japan last year. The effective substance is landiolol hydrochloride.

The administration of the ultrashort beta-blockers has been increasing continuously, both in emergency situations, when a quick heart rate control is necessary, e. g. in sinus tachycardia, fibrillation and atrium flutter (Blanski et al. 1988) and in therapy or prophylaxis of tachycardia and hypertension arising as a result of increased sympathetic activity in anaesthesia during an operation or in an after-operation phase, e. g. in laryngoscopy or intubation (Bensky et al. 2000). The ultrashort acting beta-blockers are becoming an important therapeutic group, and, consequently, the effort aiming at the synthesis of new substances bearing of these properties appear of interest.

Based on the knowledge resulting from the structure and effect relation, it is possible to presume the beta-blocking effect in compound $44 \mathrm{Bu}$, and regarding the fact that it contains an ester group in p-position on the aromatic nucleus, it is also possible to expect a short period of action due to the short biological elimination half-time. The aim of this study was to find the relation between the compound 44Bu doses and their pharmacological effect.

\section{Materials and Methods}

Tested Substance

The tested compound $44 \mathrm{Bu}$ (structure see Fig. 1) was prepared by five-step synthesis, and the structure was verified by elementary analysis, IR, ${ }^{1} \mathrm{H}-\mathrm{NMR}$, and ${ }^{13} \mathrm{C}-\mathrm{NMR}$ spectroscopy (Mokrý et al. 2001).

2-hydroxy-3-(butylamino) propyl-4-[(butoxycarbonyl) amino] benzoate hydrochloride<smiles>CCCCCCCC(O)COC(=O)c1ccc(NC(=O)O)cc1</smiles>

\begin{tabular}{|ccccc|}
\hline $\mathrm{R}^{1}$ & $\mathrm{Tt}\left({ }^{\circ} \mathrm{C}\right)$ & $\begin{array}{c}\text { Summary } \\
\text { formula }\end{array}$ & $\mathrm{Mr}$ & $\mathrm{Rf}$ \\
\hline $\mathrm{C}_{4} \mathrm{H}_{9}$ & $10--112$ & $\mathrm{C}_{19} \mathrm{H}_{31} \mathrm{~N}_{2} \mathrm{O}_{5} \mathrm{CI}$ & 402.92 & 0.69 CET 4:2:1 \\
\hline
\end{tabular}

Fig. 1. Structure of the tested substance $44 \mathrm{Bu}$

This compound belongs in the category of the newly synthesized compounds with potential beta-blocking effect with ultrashort action. The ultrashort action is achieved by the incorporation of metabolically unstable ester functional group in the linking chain of the aryloxyaminopropanol structure of original beta blockers (Mokrý et al. 2003).

In compound 44Bu similar biotransformation is supposed as in flestolol, which also belongs among the ultrashort acting beta-blockers. The ester group in the linking chain of the compound $44 \mathrm{Bu}$ is split by plasma esterases in blood plasma. It is assumed that through the action of carboxyl esterases two metabolites are formed, namely 4-alkoxycarbonyl aminobenzoic acid and 3-alkylaminopropan-1,2-diol. 
Experimental Animals

The testing was performed in vivo in fifty five male Wistar laboratory rats (body mass of $446 \pm 25 \mathrm{~g}$ ) with normal blood pressure. The animals came from a conventional breeding colony (Faculty of Medicine, Masaryk University, Brno). They were housed in agreement with the conditions as per Regulation No. 311/1997 Coll. (temperature 20-24 ${ }^{\circ} \mathrm{C}$, humidity 40-60\%, 12:12 h L:D cycles with lighting maximum up to 200 lux. They were placed in PVC cages with three animals each). The animals were fed a standard diet (Diet for small laboratory animals $\mathbf{M}_{1}$ ) and given water ad libitum.

Methodology of the experiment was approved and monitored by the local University Ethical Committee of VFU under ref. No. 12609/2003-30/300.

Experimental Design

The experiment was arranged as a comparative testing of the dose-dependent compound 44Bu action on heart rate. The measurement was taken in the group of ten rats for each dose.

Control group ( $\mathrm{n}=6$ ) was given $1 \mathrm{ml}$ of saline (placebo) in the same way.

As a comparative compound esmolol (Brevibloc ${ }^{\circledR}$ inj. Baxter Healthcare Ltd., UK) was used. The measurement was carried out in the group of six animals for each dose.

Procedure

The animals were anaesthetised using a 1\% solution of ketamine (Narkamon ${ }^{\circledR}$, inj. Spofa, Czech Republic) and $2 \%$ solution of xylazine ( Rometar $^{\circledR}$, inj. Spofa, Czech republic). Saline was used for dilution (sterile isotonic $0.9 \%$ $\mathrm{NaCl}$ solution for infusion). The anaesthetic agent was administered intramuscularly into the femur area at the dose of $0.5 \mathrm{ml} / 100 \mathrm{~g}$ of body mass.

The heart rate changes were measured on a model of induced tachycardia, which was induced by subcutaneous administration of isoprenaline (Isuprel ${ }^{\circledR}$, inj. Abbott S.p.A. Campoverde LT - Italy). In the experiment the recommended concentration $4 \mathrm{mg} \cdot \mathrm{kg}^{-1}$ of the body mass was used (Český lékopis - Czech Formulary, 1997). The heart rate reached its maximum of $150.37 \%$ of the initial value after $8-10 \mathrm{~min}$. The induced tachycardia was stable for a minimum of $30 \mathrm{~min}$ following the administration. The prepared tested substance was given intravenously into vena jugularis as a bolus dosage at a concentration of $1.5 \mathrm{mg} \cdot \mathrm{kg}^{-1}, 2.5 \mathrm{mg} \cdot \mathrm{kg}^{-1}$, and $3.5 \mathrm{mg} \cdot \mathrm{kg}^{-1} \mathrm{of}$ the body mass. The standard volume was $1 \mathrm{ml}$. The time interval of administration was $20 \mathrm{~s}$.

For monitoring the heart rate the SEIVA EKG Praktik electrocardiograph with appropriate software was used. The ECG records were made in the predetermined time intervals. The first record was taken at the beginning of the experiment after the induction of general anaesthesia, the second 10 minutes after the subcutaneous isoprenaline administration. This value corresponded with the initial value of tachycardia and it was marked as $100 \%$. Other records were made at the time of intravenous administration, further from the time of administration (marked 0) every thirty seconds up to the first minute, from the 1 st up to the $6^{\text {th }}$ minute every one minute, and from the $6^{\text {th }}$ up to the $20^{\text {th }}$ minute in two minutes intervals. The last record was made in the $25^{\text {th }}$ minute. All detected values are given in Figs 2-7.

\section{Statistical Analysis}

Statistical computations were carried out in the programs Unistat 5.1 and Microsoft Excel. A standard deviation was calculated for each value.

For the comparison of differences between placebo action and that of three different compound 44Bu concentrations (or three different esmolol concentrations) the ANOVA test was used. To reveal the statistically significant differences, Student's $t$-test (paired and unpaired) was used. By means of that, we defined the statistical significance of the observed changes of the tested substance in all three concentrations both against the control group (placebo) and the heart rate changes, which were induced by esmolol at the same concentration (see Table 1 and 2).

\section{Results}

The onset of action was very fast for all tested concentrations of 44Bu. We recorded a significant decrease of the heart rate both compared to control group (placebo) and the initial tachycardia value during the time of administration.

The maximum heart rate decrease of the $44 \mathrm{Bu}$ at the dose of $1.5 \mathrm{mg} \cdot \mathrm{kg}^{-1}$ equaled $85.36 \pm 10.14 \%$ of the initial value and it was achieved in the $3^{\text {nd }}$ minute following the intravenous administration (Fig. 2). The concentration increase to $2.5 \mathrm{mg} \cdot \mathrm{kg}^{-1}$ led to a heart rate decrease of $85.94 \pm 8.43 \%$ of the initial value in the 2 nd minute following the administration (Fig. 3). Further dose increase to $3.5 \mathrm{mg} \cdot \mathrm{kg}^{-1}$ led to a heart rate decrease only to $91.04 \pm 9.32 \%$ of the initial value (Fig. 4) in the $2^{\text {nd }}$ minute.

The significant heart rate decrease in comparison to placebo lasted minimally up to the $14^{\text {th }}$ minute following the intravenous administration for all three concentrations - at the dose of $1.5 \mathrm{mg} \cdot \mathrm{kg}^{-1}$ of 


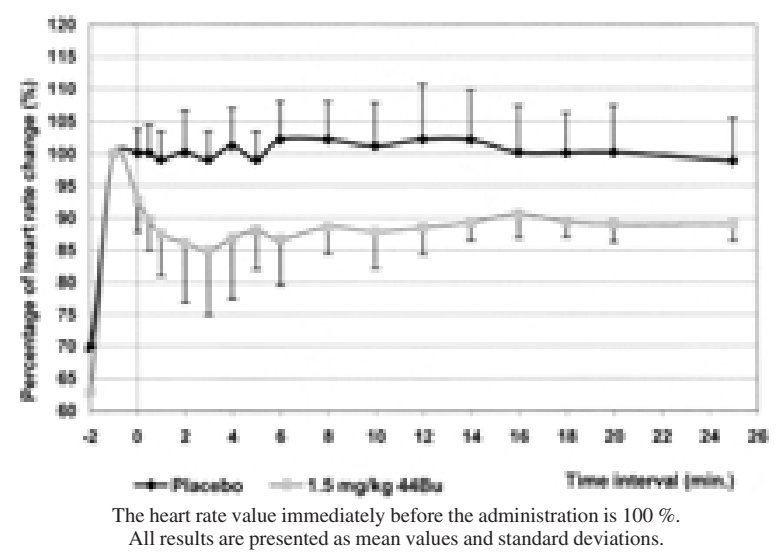

Fig. 2. Heart rate change (in \%) following the administration of $44 \mathrm{Bu}$ at the concentration of $1.5 \mathrm{mg} \cdot \mathrm{kg}^{-1}$

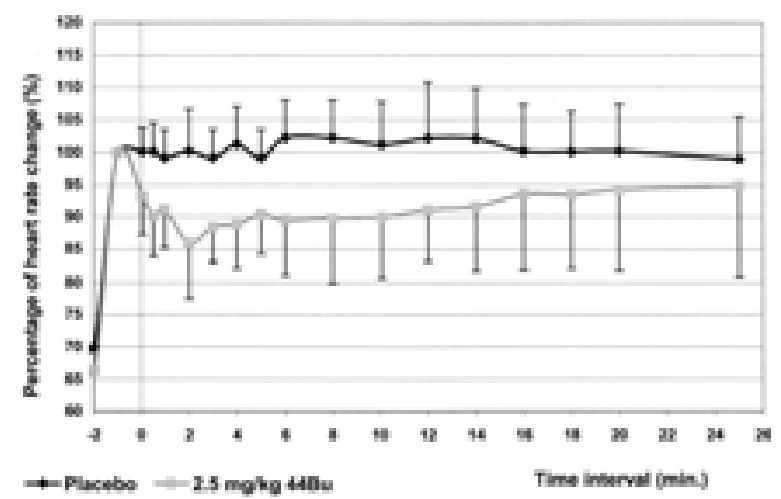

The heart rate value immediately before the administration is $100 \%$. All results are presented as mean values and standard deviations.

Fig. 3. Heart rate change (in \%) following the administration of $44 \mathrm{Bu}$ at the concentration of $2.5 \mathrm{mg} \cdot \mathrm{kg}^{-1}$

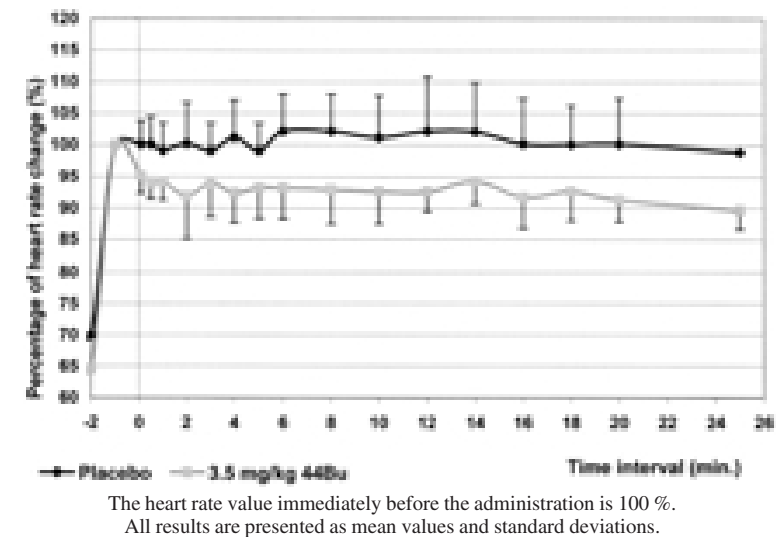

Fig. 4. Heart rate change (in \%) following the administration of $44 \mathrm{Bu}$ at the concentration of $3.5 \mathrm{mg} \cdot \mathrm{kg}^{-1}$ the body mass the heart rate decrease was significant even up to the $25^{\text {th }} \mathrm{mi}-$ nute following the intravenous administration (Table 1).

Immediately after the intravenous administration of the compound $44 \mathrm{Bu}$, we recorded very distinct changes in ECG record concerning above all PQ interval, QRS complex, QT interval, and moreover S, R wave and T wave (B artošová et al. 2003).

Also the onset of action of esmolol was very fast. The statistically significant heart rate decrease in comparison to placebo occurred during the time of administration. The maximum heart rate decrease of esmolol at the dose of $1.5 \mathrm{mg} \cdot \mathrm{kg}^{-1}$ equaled $80.94 \pm 7.24 \%$ of the initial value and it was achieved in the $2^{\text {nd }}$ min following the intravenous administration (Fig. 5). The concentration increase of esmolol to $2.5 \mathrm{mg} \cdot \mathrm{kg}^{-1}$ led to a heart rate decrease to $75.6 \pm 6.23 \%$ of the initial value in the $30^{\text {th }}$ second following the intravenous administration (Fig. 6). Further dose increase of esmolol to $3.5 \mathrm{mg} \cdot \mathrm{kg}^{-1}$ led to even more distinct heart rate decrease, the maximum equaled 70.55 $\pm 2.85 \%$ of the initial value and it was reached in the $30^{\text {th }}$ second following the intravenous administration (Fig. 7, Table 2).

\section{Discussion}

The substance tested with the working name 44Bu belongs to the category of potential drugs with the ultrashort acting beta-blocking action. From the chemical point of view it is a 2-hydroxy-3-(butylamino) propyl-4-[(butoxycarbonyl) amino] benzoate hydrochloride.

All the tested concentrations of the compound 44Bu caused the significant heart rate decrease against placebo (Fig. 2-4). Immediately after the intravenous administration of $44 \mathrm{Bu}$ distinct changes in ECG record were observed (for actual results see Brunclík et al. 2003). 


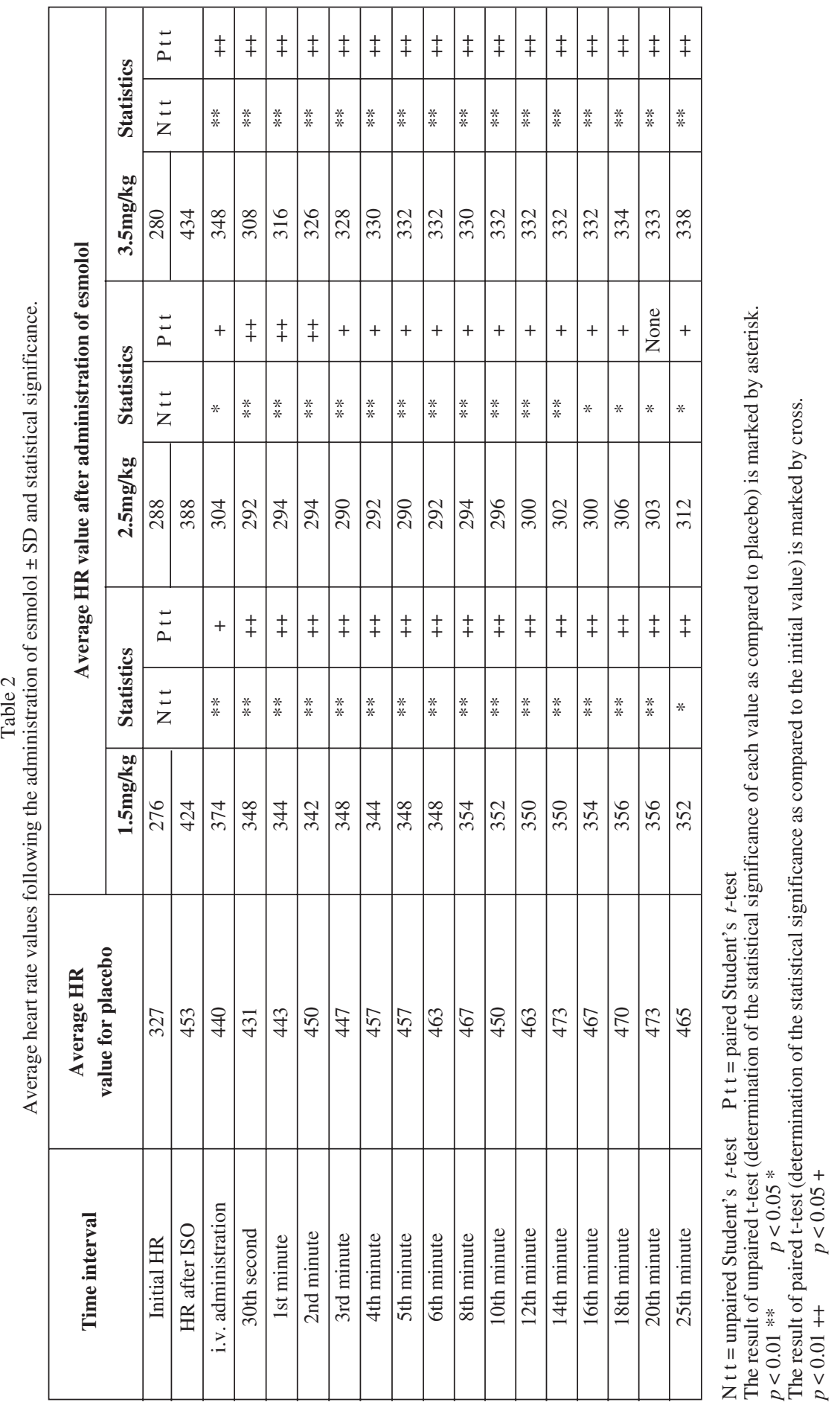




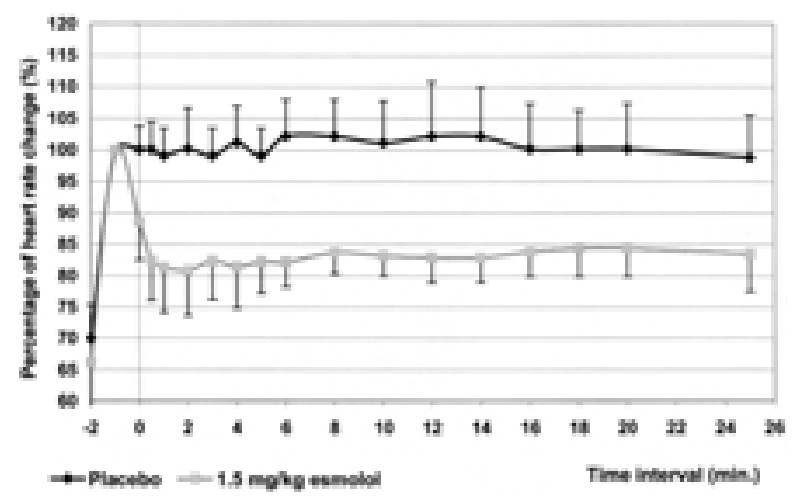

The heart rate value immediately before the administration is $100 \%$. All results are presented as mean values and standard deviations.

Fig. 5. Heart rate change (in \%) following the administration of esmolol at the concentration of $1.5 \mathrm{mg} \cdot \mathrm{kg}^{-1}$

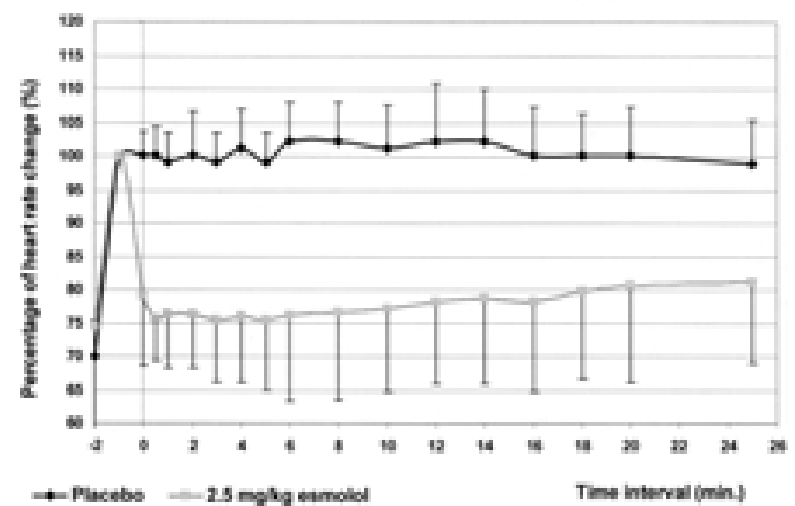

The heart rate value immediately before the administration is $100 \%$. All results are presented as mean values and standard deviations.

Fig. 6. Heart rate change (in \%) following the administration of esmolol at the concentration of $2.5 \mathrm{mg} \cdot \mathrm{kg}^{-1}$

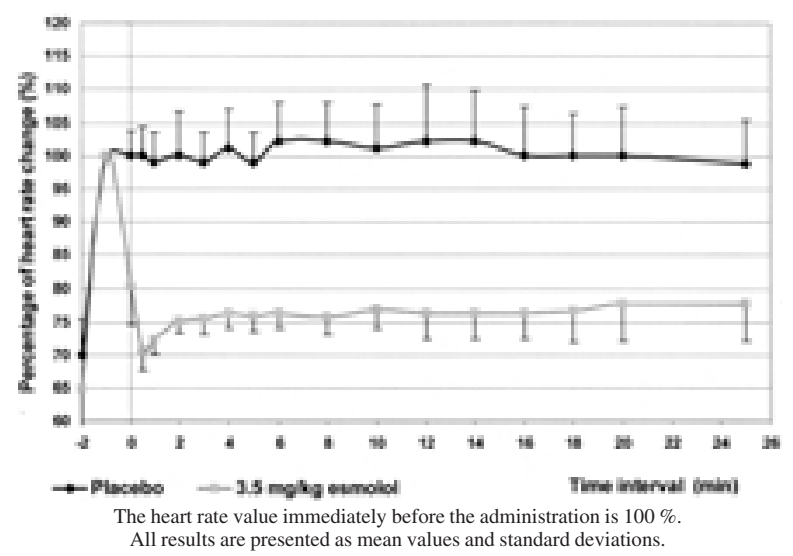

Fig. 7. Heart rate change (in \%) following the administration of esmolol at the concentration of $3.5 \mathrm{mg} \cdot \mathrm{kg}^{-1}$
Between the effect of the concentration $1.5 \mathrm{mg} \cdot \mathrm{kg}^{-1}$ (heart rate decrease by $14.64 \pm 10.14 \%$ against the initial value or by $14.26 \%$ against placebo) and $2.5 \mathrm{mg} \cdot \mathrm{kg}^{-1}$ no significant difference was found. Consequently, we can conclude that the bradycardic effect is reached at the concentration of $1.5 \mathrm{mg} \cdot \mathrm{kg}^{-1}$ and by the dose increase no stronger therapeutic effect, i.e. heart rate deeper decrease, is achieved.

The increase of concentration to $2.5 \mathrm{mg} \cdot \mathrm{kg}^{-1}$ meant only a faster achievement of the maximum heart rate decrease and also a faster return to the initial value $-90 \%$ value of the initial status is reached in the $5^{\text {th }} \mathrm{mi}$ nute in concentration $2.5 \mathrm{mg} \cdot \mathrm{kg}^{-1}$, while with the concentration $1.5 \mathrm{mg} \cdot \mathrm{kg}^{-1}$ the same result was seen only in the $16^{\text {th }}$ minute.

The highest administered concentration $\left(3.5 \mathrm{mg} \cdot \mathrm{kg}^{-1}\right)$ manifested itself in a heart rate decrease by 8.06 $\pm 6.87 \%$ against the initial value, or by $8.26 \%$ against placebo.

The tested compound $44 \mathrm{Bu}$ has besides the bradycardic effect, also a hypotensive effect. At the administration of the dose over $3 \mathrm{mg} \cdot \mathrm{kg}^{-1}$ the compound 44Bu induced a sharp decrease of arterial blood pressure, which led to consequent engagement of the compensation mechanisms of the organism. This phenomenon was not observed at lower concentrations (Frydrych 2003). The engagement of these compensation mechanisms attempting to increase the blood pressure by the heart rate increase offers the explanation of the lower bradycardic effect of the highest concentration tested in this experiment.

If we compare the action of the compound $44 \mathrm{Bu}$ and esmolol, we find that they are not different in the onset of action, but in the depth of the heart rate decrease, above all at higher concentrations. On the contrary, at the concentration of 
$1.5 \mathrm{mg} \cdot \mathrm{kg}^{-1}$ no significant difference was found between the influence of the compound $44 \mathrm{Bu}$ and esmolol on the heart rate during the first 14 minutes. During the 25 minutes of monitoring the heart rate after the intravenous administration of esmolol was kept under the limit of $85 \%$ of the initial value, after the administration of $44 \mathrm{Bu}$ under the limit of $95 \%$ of the initial value.

The results of the previous experiments confirm that the compound 44Bu reduces the heart rate in the laboratory rat from the physiological level - the maximum heart rate decrease following the compound 44Bu administration at the dose of $2.5 \mathrm{mg} \cdot \mathrm{kg}^{-1}$ was $13.00 \pm 5.53 \%$ of the initial value (Bartošová et al. 2002). Isoprenaline-induced tachycardia model showed that the administration of a dose of the same concentration led to the heart rate decrease by $14.06 \pm 8.43$ $\%$ of the initial value. No significant differences were found between these figures.

The compound 44Bu decreases the heart rate of the same percentage regardless of the initial value of the heart rate (base line or tachycardia induced by sympatomimetic drugs). In this effect $44 \mathrm{Bu}$ differs from the effects of other ultrashort-acting beta blockers. All the so far existing experiments points, that heart rate decrease is probably caused not only via beta receptors and $\mathrm{Ca}^{2+}$ ion channels, but also via $\mathrm{Na}^{+}$ion channels.

Based on the above facts, it may be assumed that the tested compound does not fully antagonize isoprenaline effect. Besides the beta-blocking activity it also possesses a partial sympathomimetic activity. However, it is also possible, that the heart rate decrease is determined only by the dromotropic effect of the compound in the myocardium, i. e. by a distinct prolongation of PQ interval. This anti-arrhythmic activity results from the compound $44 \mathrm{Bu}$ capability to block the fast sodium current $\mathrm{I}_{\mathrm{Na}}$ and the transient outward potassium current $\mathrm{I}_{\text {to }}$ in cardiomyocytes (B artošová et al. 2003).

It was experimentally documented that the newly synthesized compound 44Bu has a significant bradycardic effect at all tested concentrations. The onset of action was very fast and comparable with esmolol. Significant heart rate changes were recorded during $30 \mathrm{~s}$ following the intravenous administration. The lowest dosage of the tested substance $\left(1.5 \mathrm{mg} \cdot \mathrm{kg}^{-1}\right)$ proved as the most convenient because at this dose the deepest and most stable heart rate decrease was reached with a maximum of $14.64 \pm 10.14 \%$. With increasing concentration of $44 \mathrm{Bu}$, the influence on the heart rate was not increased, which supports the hypothesis that the compound 44Bu has, besides a betasympatholytic activity, also an intrinsic sympathomimetic activity. On the contrary, with increasing concentration of esmolol its influence on the heart rate also increases.

Statistically significant heart rate change against placebo was recorded at the concentration $1.5 \mathrm{mg} \cdot \mathrm{kg}^{-1}$ in $25 \mathrm{~min}$, at concentrations 2.5 and $3.5 \mathrm{mg} \cdot \mathrm{kg}^{-1}$ in $14 \mathrm{~min}$ following the intravenous administration. It was demonstrated that the ultrashort acting time of $44 \mathrm{Bu}$ is based on its chemical structure.

\section{Schopnost nově syntetizovaného ultrakrátkého blokátoru beta adrenergních receptorů 44Bu antagonizovat izoprenalinem vyvolanou tachykardii - porovnání s esmololem}

Cílem této práce bylo otestovat in vivo účinek tř́i nově syntetizovaných potenciálních ultrakrátkých $\beta$ blokátorů na srdeční frekvenci laboratorního potkana. Testovaná látka byla aplikována zviŕatům s indukovanou tachykardií v celkové anestézii formou intravenózního bolusu. Testovány byly dávky $1,5 \mathrm{mg} \cdot \mathrm{kg}^{-1}, 2,5 \mathrm{mg} \cdot \mathrm{kg}^{-1}$ a $3,5 \mathrm{mg} \cdot \mathrm{kg}^{-1} \mathrm{hmotnosti} \mathrm{zvířete}$ a účinnost porovnána proti placebu. Pro monitorování srdeční frekvence byl použit počítačový elektrokardiograf. Statisticky významný pokles srdeční frekvence $(p<0,05)$ byl zaznamenán u všech tří testovaných dávek a to minimálně do 14. minuty od i.v. aplikace. Bradykardický účinek látky $44 \mathrm{Bu}$ byl porovnán s působením esmololu za stejných experimentálních podmínek. Působení látky 44Bu a esmololu se neliší v rychlosti nástupu účinku, ale v hloubce poklesu srdeční frekvence především při vyšších koncentracích. Experimentálně jsme ověřili, že látka 44Bu má vlastnosti ultrakrátce působících blokátorů beta adrenergních receptorů. 


\section{Acknowledgement}

This work was supported by Research intention No. 163700003 and No. 161700002 (Ministry of Education, Youth and Sport, Czech Republic).

\section{References}

ATARASHI, H, KURUMA, A, YASHIMA, M, SAITOH, H, INO, T, ENDOH, Y, HAYAKAWA, H 2000: Pharmacokinetics of landiolol hydrochloride, a new ultra-short acting beta-blocker, in patients with cardiac arrhythmias. Clin Pharmacol Ther. 68: 143-150

BARTON, SD, BURGE, J, TURLAPATY, P, LADDU, AR 1986: Flestolol: an ultra-short-acting beta-adrenergic blocking agent, J Clin Pharmacol. 26: Suppl A, A36-A39

BARTOŠÍKOVÁ, L, NEČAS, J, PAVLÍČEK, V, KUCHTIČKOVÁ, Š, FRÁŇA, P, ZAVADILOVÁ, R, HUŠEK, K 1998: Study of the effect of the sympatolytic carvedilol in the conditions of experimental alloxan diabetes in the laboratory rat. Čs a slov farm 47: 151-154

BARTOŠOVÁ, L, FRYDRYCH, M, BARTOŠÍKOVÁ, L, FLORIAN, T, MOKRÝ, P, BRUNCLÍK, V, NEČAS, J, 2002: Observation of changes in heart rate after newly developed ultrashort acting beta-adrenergic blockers were applied. Bratisl Lek Listy; 103: 303-304

BARTOŠOVÁ, L, FRYDRYCH, M, MOKRÝ, P, BRUNCLÍK, V, KOTOLOVÁ, H 2003: Changes in heart rate after application of newly developed ultrashort acting beta-adrenergic blockers. Pharmazie 58: 841-842

BENSKY, KP, DONAHUE-SPENCER, L, HERTZ, GE, ANDERSON, MT, JAMES, R 2000: The dose related effects of bolus esmolol on heart rate and blood pressure following laryngoscopy and intubation. AANA J, 68: 437-42

BLANSKI, L, LUTZ, J, LADDU, A 1988: Esmolol, the first ultra-short-acting i.v. beta blocker for use in critically ill patiens. Heart Lung. 17: 80-89

BRUNCLÍK, V, BARTOŠOVÁ, L, SEDLÁK, P, KOLEVSKÁ, J, FRYDRYCH, M, NEČAS, J 2003: Elektrofyziologické účinky ultrakrátkých beta blokátorů na myokard laboratorního potkana. Čs. Fyziologie 52: A2

ČESKÝ LÉKOPIS (ČL 97) (Czech Formulary) 1997: Grada Publishing, Praha, 1.díl.

FELIX, SB, STANGL, V, KIEBACK, A, DOERFFEL, W, STAUDT, A, WERNECKE, KD, BAUMANN, G, STANGL, K 2001: Acute hemodynamics effects of beta blockers in patiens with severe congestive heart failure: comparison of celiprolol and esmolol. J Cardiovasc Pharmacol 38: 666-71

FRYDRYCH, M 2003: Testování nových ultrakrátce působících beta blokátorů in vivo - doctorate thesis FaF VFU Brno, p. 56-57

GORCZYNSKI, RJ 1985: Basic pharmacology of esmolol. Am J Cardiol 56: 3F-13F

GRAY, RJ 1988: Managing critically ill patients with esmolol. Chest 93: 398-403

HRADEC, J, SPÁČIL, J 2002: Kardiologie, angiologie; vnitřní lékařství; svazek II, vydavatelství Galén

KATZUNG, BG 1995 : Základní a klinická farmakologie, nakladatelství a vydavatelství H\&H, Jinočany. (Basic and clinical pharmacology, Publishing house H\&H, Jinočany)

LÜLLMANN, H, MOHR, K, ZIEGLER, A, BIEGER, D 2001: Barevný atlas farmakologie, 2., přepracované a doplněné vydání. Grada Publishing Praha

MIKROVERZE AUTOMATIZOVANÉHO INFORMAČNÍHO SYSTÉMU LÉČIVÝCH PŘÍPRAVKU゚ PRO AUTONOMNÍ VYUŽITÍ VE ZDRAVOTNICKÝCH ZAŘÍZENÍCH AISLP verze 9.0; Praha 2002. (Microversion of automated information system of medicinal preparations for autonomous application in medical facilities)

MOKRÝ, P, CSÖLLEI, J, RAČANSKÁ, E, TUMOVÁ, I, ZEMANOVÁ-DURMISOVÁ, M. 2001: Syntéza a studium potenciálních blokátorů beta-adrenergních receptorů s ultrakrátkým účinkem. $30^{\text {th }}$ conference Synthesis and analysis of drugs. $87 \mathrm{p}$.

MOKRÝ, P, ZEMANOVÁ, M, CSÖLLEI, J, RAČANSKÁ, E, TUMOVÁ, I 2003: Synthesis and pharmacological evaluation of novel potential ultrashort-acting $\beta$-blockers. Pharmazie 58: 18-21

NEČAS, J, BARTOŠÍKOVÁ, L, DRÁPELOVÂ, L, HUŠEK, K, PAVLÍČEK, V, KUCHTIČKOVÁ, S. 1997: The effects of Carvedilol, a beta-blocker, in experimental ischemia-reperfusion kidney injury. Vnitř Lék 43: 707-711

REILLY, CS, WOOD, M, KOSHAKJI, RP, WOOD, AJ 1985: Ultra-short acting beta-blockade: a comparison with conventional beta-blockade. Clin Pharmacol Ther 38: 579-85 